Scalar adherence of denumerals and numerals appears due to their correlation to lexical-semantic field of quantity, that is marked by definitions of discrete referents, the ability of dequantification, phraseologization and desemantization, up to word-creation. Differences between denumerals and numeral words are in modifications of formal structures, semantic deviations, word formation vectors, aspects of object semantisation, discreteness and correlation with number denotation.

The theoretical significance of this article contains in the expansion of the ideas about the ontological, cognitive and linguistic nature of denumerals, their role in the linguistic pattern of the world.

\title{
References:
}

1. Shvachko S. Polyfunctionality of the English Quantitative Words/ Journal of Education Culture and Society. 2013. № 2. P. 208-214.

2. Medvid O. System and Functional Properties of Quantitative Units, (Sistemno-functsionalnyie osobennosti kvantitativnukh edinits). Kharkiv, 2001. URL: http:www.lib.ua-ru.net/inode/5859.html

DOI https://doi.org/10.30525/978-9934-26-073-5-1-71

\section{СПОСОБИ УТВОРЕННЯ НЕОЛОГІЗМІВ, ЯКІ ВИКОРИСТОВУЮТЬСЯ ПРИ ВИСВІТЛЕННІ ПОДІЙ, ПОВ'ЯЗАНИХ ІЗ ПАНДЕМІЄЮ COVID-19}

\author{
Сивак А. О. \\ викладач англійської мови кафедри латинської та іноземних мов \\ Львівського начіонального медичного університету \\ імені Данила Галищького \\ м. Львів, Україна
}

Словниковий запас англійської мови стрімко розвивається за рахунок іншомовних запозичень, утворення неологізмів, появи нових значень слів, що вже використовуються. Засоби масової інформації, а саме: телебачення, Інтернет, соціальні мережі - дали змогу виокремити лексику, до якої найчастіше вдаються автори при висвітленні подій, пов'язаних із пандемією COVID-19. Вивчаючи статті, програми, дописи, результати досліджень університетів, пов'язаних із карантином, локдауном, захворюваністю та вакцинацією, ми не можемо не звернути увагу на те, що 2019 та 2020 роки збагатили англійську мову 
надзвичайно великою кількістю неологізмів, які застосовують не лише науковці, але й пересічні громадяни, для яких нещодавно утворені лексичні одиниці стали способом чіткого висловлення понять, пов'язаних із COVID-19.

Ключові слова: неологізм, спосіб утворення, деривація, конверсія, основоскладання, скорочення, злиття, акроніми.

Отже, завданням $є$ дослідити шляхи утворення неологізмів та визначити найбільш вживаний спосіб на прикладі статей британських та американських газет «The Guardian», «The Washington Post» та «The New York Times», які висвітлюють події, пов'язані з COVID-19.

Актуальність дослідження полягає у вивченні пов'язаних із COVID-19 неологізмів, які 3'явились упродовж останніх двох років у мас-медіа, вдаючись до методу компонентного аналізу та визначаючи спосіб творення.

Застосовуючи метод компонентного аналізу, запропонованого американським вченим Дж. Фодором, досліджуватимемо кожен неологізм, а саме: 1) зазначатимемо частину мови (досліджуватимемо іменники); 2) визначатимемо значущі частини слова; 3) досліджуватимемо значення сем; 4) прослідкуємо вплив сем на значення слова в цілому [4, с. 198]. Також будемо досліджувати способи творення.

Досліджуючи питання неологізмів, звертаємо увагу на те, що існує надзвичайно велика кількість дефініцій до терміну, запропонованих науковцями, а саме: О. С. Ахмановою, В. В. Лопатіним, М. І. Мостовим, Н. І. Фельдманом, Дж. Алгео, Р. Фішером та іншими.

О. С. Ахманова стверджує, що неологізми - це слова чи словосполучення, створені для позначення нового чи раніше невідомого об'єкта або вираження нового поняття, наголошуючи на номінативній функції неологізмів [1, с. 15]. Дж. Алгео визначає неологізми, як новостворені слова або значення існуючих слів, які виникають 3 метою надання назви новому поняттю [2, с. 4$]$.

Неологізми класифікують за видом мовної одиниці (неолексеми, неофраземи, неосеми), за ступенем новизни (абсолютні та відносні неологізми), за видом означуваної реалії (можуть позначати нову, стару, актуалізовану, відмираючу, неіснуючу реалію), за способом утворення (запозичені внутрішні та зовнішні, словотвірні та семантичні) [3, с. 98].

Словниковий запас англійської мови може збагачуватись завдяки: derivation, conversion, compounding, clipping, blending. Для того, щоб дослідити неологізми, які були створені за допомогою вище зазначених способів: 1) обираємо 20 статей із англомовних інтернет-видань «The Guardian», «The Washington Post» та «The New York Times»; 
2) знаходимо неологізми та класифікуємо за способом утворення; 3) визначаємо компоненти, із яких утворені неологізми; 4) прослідкуємо вплив значення компонентів на неологізм в цілому.

Отже, у статтях були знайдені приклади використання різних способів створення неологізмів [3, с. 88]: 1) derivation деривація чи affixation (додавання суфіксів або префіксів): maskless (без маски); 2) conversion конверсія чи zero-derivation (перехід слова від однієї частини мови в іншу): quarantine (ім.) - карантин $\rightarrow$ to quarantine (дієсл.)дотримуватись карантину; 3) compounding чи основоскладання передбачає об'єднання двох або більше слів (основ) з метою утворення одного: lockdown, self-isolation;

\begin{tabular}{|c|c|c|c|c|c|}
\hline № & Неологізм & $\begin{array}{c}\text { Частина } \\
\text { мови }\end{array}$ & \multicolumn{2}{|c|}{ Складові та їх значення } & $\begin{array}{c}\text { Значення } \\
\text { неологізму }\end{array}$ \\
\hline 1 & Zumping & $\begin{array}{l}\text { Noun/ iм. } \\
\text { незлічува } \\
\text { ний }\end{array}$ & $\begin{array}{c}\text { Zоот - } \\
\text { Мережа, } \\
\text { яка } \\
\text { забезпечує } \\
\text { можливість } \\
\text { проведення } \\
\text { відео } \\
\text { конфе- } \\
\text { ренцій }\end{array}$ & $\begin{array}{c}\text { Dumping } \\
\text { Припинення } \\
\text { романтичних } \\
\text { стосунків із } \\
\text { кимось }\end{array}$ & $\begin{array}{c}\text { Закінчення } \\
\text { стосунків в } \\
\text { режимі відео } \\
\text { зв'язку через } \\
\text { розбіжності } \\
\text { внаслідок } \\
\text { самоізоляції }\end{array}$ \\
\hline 2 & $\begin{array}{c}\text { Zoom- } \\
\text { bombing }\end{array}$ & $\begin{array}{l}\text { Noun/ ім. } \\
\text { незлічува } \\
\text { ний }\end{array}$ & $\begin{array}{l}\text { Zoom - } \\
\text { Мережа }\end{array}$ & $\begin{array}{c}\text { Bombing - } \\
\text { бомбардуванн } \\
\text { я }\end{array}$ & $\begin{array}{c}\text { Порушувати } \\
\text { порядок під час } \\
\text { онлайн } \\
\text { конференції, } \\
\text { вдаючись до } \\
\text { образливих слів }\end{array}$ \\
\hline 3 & $\begin{array}{l}\text { Doom- } \\
\text { scrolling }\end{array}$ & $\begin{array}{c}\text { Noun/ iм. } \\
\text { незлічува } \\
\text { ний }\end{array}$ & $\begin{array}{l}\text { Doom } \\
\text { Доля, } \\
\text { фатум }\end{array}$ & $\begin{array}{c}\text { Scrolling } \\
\text { Пересування } \\
\text { тексту вниз } \\
\text { по цифровому } \\
\text { екрану }\end{array}$ & $\begin{array}{c}\text { Постійно } \\
\text { оновлювати } \\
\text { новини з метою } \\
\text { отримання } \\
\text { найактуальніши } \\
\text { х повідомлень } \\
\text { щодо пандемії }\end{array}$ \\
\hline
\end{tabular}

4) clipping означає скорочення існуючого слова: influenza $\rightarrow$ flu, coronavirus $\rightarrow$ rona; iso $\rightarrow$ isolation; quaz_ $\rightarrow$ quarantine. 5) blending чи злиття створюється за допомогою використання перших складів одного слова та останніх складів другого: covidivorce = Corona Virus + Divorce, coronageddon $=$ Corona Virus + Armageddon; 
International scientific and practical conference

\begin{tabular}{|c|c|c|c|c|c|}
\hline № & Неологізм & Частина & \multicolumn{2}{|c|}{ Складові та їх значення } & Значення \\
\hline 1 & E-peritif & $\begin{array}{l}\text { Noun/ ім. } \\
\text { злічуваний }\end{array}$ & $\begin{array}{l}\text { Epidemic } \\
\text { Епідемія }\end{array}$ & $\begin{array}{c}\text { Аperitif } \\
\text { Алкогольний } \\
\text { напій, що } \\
\text { вживається } \\
\text { перед } \\
\text { споживанням } \\
\text { іжі }\end{array}$ & $\begin{array}{c}\text { Алкогольний } \\
\text { напій, що } \\
\text { вживається } \\
\text { під час } \\
\text { відео- } \\
\text { зустрічей із } \\
\text { друзями } \\
\end{array}$ \\
\hline 2 & Covexit & $\begin{array}{c}\text { Noun/ iм. } \\
\text { незлічуваний }\end{array}$ & $\begin{array}{l}\text { Corona virus } \\
\text { Коронавірус }\end{array}$ & $\begin{array}{c}\text { Exit } \\
\text { Вихід }\end{array}$ & $\begin{array}{c}\text { Стратегія } \\
\text { виходу з } \\
\text { суворої } \\
\text { ізоляції }\end{array}$ \\
\hline 3 & Coronacation & $\begin{array}{l}\text { Noun/ ім. } \\
\text { злічуваний }\end{array}$ & $\begin{array}{l}\text { Corona virus } \\
\text { Коронавірус }\end{array}$ & $\begin{array}{c}\text { Staycation } \\
\text { Stay - } \\
\text { залишатись } \\
\text { Vacation - } \\
\text { відпустка } \\
\text { Слово } \\
\text { означає } \\
\text { залишатись } \\
\text { вдома під час } \\
\text { відпустки, } \\
\text { а не подоро- } \\
\text { жувати }\end{array}$ & $\begin{array}{c}\text { Відпустка, } \\
\text { яку ви } \\
\text { проводите } \\
\text { вдома через } \\
\text { скасовані } \\
\text { заняття чи } \\
\text { зміни }\end{array}$ \\
\hline 4 & Infodemic & $\begin{array}{c}\text { Noun/ ім. } \\
\text { незлічуваний }\end{array}$ & $\begin{array}{l}\text { Information } \\
\text { Інформація }\end{array}$ & $\begin{array}{c}\text { Epidemic } \\
\text { Епідемічний }\end{array}$ & $\begin{array}{c}\text { Швидке } \\
\text { поширення } \\
\text { хибної } \\
\text { інформації }\end{array}$ \\
\hline 5 & Blursday & $\begin{array}{l}\text { Noun/ ім. } \\
\text { злічуваний }\end{array}$ & $\begin{array}{c}\text { To blur } \\
\text { Робити } \\
\text { неясним, } \\
\text { нечітким }\end{array}$ & $\begin{array}{l}\text { Day } \\
\text { День }\end{array}$ & $\begin{array}{c}\text { Невідомий } \\
\text { день тижня } \\
\text { через } \\
\text { дезорієнтую } \\
\text { чий вплив } \\
\text { карантину }\end{array}$ \\
\hline
\end{tabular}

6) acronyms (акроніми) формуються завдяки комбінуванню перших літер чи складів усіх чи кількох елементів складного терміна: ARDS Acute Respiratory Distress Syndrome; COVID - Corona Virus Disease. 


\begin{tabular}{|c|c|c|c|c|}
\hline № & $\begin{array}{c}\text { Акронім/ } \\
\text { абревіатура }\end{array}$ & Частина мови & $\begin{array}{c}\text { Складові та їх } \\
\text { значення }\end{array}$ & Значення акроніма \\
\hline 1 & $\begin{array}{c}\text { WFH } \\
\text { Абревіатура }\end{array}$ & $\begin{array}{c}\text { Noun/ ім. } \\
\text { незлічуваний }\end{array}$ & $\begin{array}{c}\text { Work From } \\
\text { Home }\end{array}$ & Робота з дому \\
\hline 2 & $\begin{array}{c}\text { PРE } \\
\text { Абревіатура }\end{array}$ & $\begin{array}{c}\text { Noun/ ім. } \\
\text { незлічуваний }\end{array}$ & $\begin{array}{c}\text { Personal } \\
\text { Protective } \\
\text { Equipment }\end{array}$ & $\begin{array}{c}\text { Засоби } \\
\text { індвідуального } \\
\text { захисту }\end{array}$ \\
\hline 3 & $\begin{array}{c}\text { ВCV } \\
\text { Абревіатура }\end{array}$ & Noun/ ім. & $\begin{array}{c}\text { Before Corona } \\
\text { Virus }\end{array}$ & $\begin{array}{c}\text { Час до поширення } \\
\text { коронавірусної } \\
\text { інфекції }\end{array}$ \\
\hline 4 & $\begin{array}{c}\text { WНО } \\
\text { Абревіатура }\end{array}$ & $\begin{array}{c}\text { Noun/ ім. } \\
\text { злічуваний }\end{array}$ & $\begin{array}{c}\text { World Health } \\
\text { Organization }\end{array}$ & $\begin{array}{c}\text { Всесвітня організація } \\
\text { охорони здоров'я }\end{array}$ \\
\hline
\end{tabular}

Підбиваючи підсумки, можемо прослідкувати те, що в 20 статтях зустрілось 24 неологізми, які були утворені завдяки різним способам, а came: blending 29\%; compounding $21 \%$, clipping $17 \%$, abbreviations $17 \%$, acronyms $8 \%$, derivation $4 \%$, conversion $4 \%$.

Отже, найпродуктивнішим $€$ blending, основоскладання посідає друге місце, clipping та використання абревіатур посідають третю позицію, наступними за частотою вживання $є$ акроніми. Не так часто, в порівнянні із іншими способами, зустрічаються деривація та конверсія.

Таким чином, усвідомлюємо, що виникнення та поширення неологізмів відображає появу нових реалій у спільноті носіїв мови. Неологізми виникають для позначення нового поняття, феномену чи події. Також досить часто вони $є$ емоційно забарвлені, передають ставлення носіїв мови до подій. Досліджуючи неологізми, ми краще розумісмо реалії, із якими стикаються носії мови. Результати даного дослідження можна застосовувати під час занять 3 англійської мови, адже це підготує учнів чи студентів до того, із чим вони стикнуться у новинах, на сторінках газет чи у соціальних мережах. Це допоможе краще зрозуміти зміст тексту та задум автора. Перспективою дослідження $є$ можливість продовження аналізу неологізмів, пов'язаних із пандемією COVID-19 та інших тем, які висвітлюють ЗMI.

\section{Література:}

1. Akhmanova O. S., Dictionary of Linguistic terms. M., 1966. 608 p.

2. Algeo J. Fifty Years Among the New Words: a dictionary of neologisms, 1941-1991. New York, 1991. $257 \mathrm{p}$.

3. Brinton L.J., Brinton D. M., The Linguistic Structure of Modern English. Philadelphia, 2010. 446 p.

4. Fedorenko O. I., Sukhorolska S. M., Ruda O. V., Fundamentals of linguistic research. Lviv, 2009. 296 p. 